\title{
Visual Modelling Principles in Urban Planning
}

\author{
Ilze Paklone, Riga Technical University
}

ABSTRACT. This paper examines legally non-binding visual modelling principles. The recent inquires in urban planning indicate that legally non-binding visual modelling principles have become important tools to develop and communicate the key messages in urban planning. Analysis is focused on taxonomy of visual modelling principles and notions that are related to visual representation and modelling. Selected visual modelling principles can serve as examples of how to organize legally non-binding process of urban planning in Latvia.

KEYWORDS: vfunctions of visual representation, scenarios, spatial visions, types of visual representation, urban planning, visual modelling principles.

In the first decades of the 21 st century, urban planning has transformed into an open and cross-disciplinary process. Urban planning is no longer a closed discipline, which brings together only architects-urban planners and other experts. This aspect is a challenge for architects-urban planners to model urban planning strategies in a specific visual mode, which is explicit not only to experts, but also to the audience of non-experts the main decision makers of strategic issues. A specialist of modelling in urban planning Peter Moll emphasises that visual modelling in urban planning requires two types of competence. One is to understand and visualise simultaneously existent spatial complexity, the possible reality and the consequences of urban planning strategies. The other competence is to communicate the complexity of urban planning strategies to various participants to reach agreements already during the modelling process [6, 58 ]. Visual representation has always been the primary mode of expressing ideas in architecture and urban planning. However, during the last decades technological potential, cross-disciplinary cooperation and the shift of important themes in urban planning have caused unpredicted possibilities to create new principles of visual modelling or elaborate existing ones $[2 ; 4 ; 6 ; 9 ; 10 ; 14$; $15 ; 16]$.

In 2001, the director of "Xerox" Palo Alto Research Centre John Seely Brown argues that at present science is driven by the tools and not by theory; tools have completely changed the speed and nature of innovation and possible research modes, and tools have also determined, what kind of questions can be asked and how they can be answered [8, 306]. Also, the researcher of the visual images used in science Barbara Maria Stafford believes that the construction of scientific databases and knowledge is primarily supported by visual representation, which serves as scientific evidence and a tool for analytical research $[14,5]$. Cross-disciplinary studies mainly accentuate interpretation of visual representation on the basis of visually aesthetic and semiotic analysis. Nevertheless, visual representation in urban planning is predominantly a modelling tool, which shows the mode of structuring information and allows the tracking of the development of architectural thinking. Therefore, the inquiry of visual aspects in urban planning is based on the cross-disciplinary research, as well as on the theoretical assumptions and on the examination of practical examples of urban planning itself. The tendencies that set the trends of research design methodologies in art disciplines, architecture and urban planning indicate that the prevailing course is integration of artistic and scientifically analytic approaches. This integrated research design mode is known as research by design methodology [9, 6-19].

The integration of artistic and scientifically analytic approaches is also a framework for the analysis of visual representation and visual modelling principles. This trend positions visual representation not only as a direct or associative depiction of a current or future situation, but mainly as a principle of visual analysis, a scientific document and art work at the same time. Such a correlation of various assumptions is linked to the principles of how to model visually - how to structure information and how to model new possibilities. Visual modelling principles can be one of the legally non-binding tools for the development of urban planning strategies as architectonically spatial concepts and spatial argumentation for legally binding urban planning documentation, i.e. thematic mappings and building regulations. Both the audience of experts and non-experts can understand architectonically spatial argumentation, rather than generalised parameters of development.

The purpose of this paper is to systematise fundamental visual modelling principles that can be applicable to model, to promote and communicate urban planning strategies as they are modelled. The main tasks, which are based on the aim of the paper, include classification of the basic types and functions of visual representation, methods for developing strategies in urban planning and criteria for analysing visual representation and visual modelling principles. This approach aims at integrating the possibilities of existing visual modelling principles.

The term visual representation is used in this article to indicate the distinction between visual representation itself (representation, depiction of something) and idea, notion, conception, strategy and image. The term visual representation in urban planning is considered both a single depiction and a complex set of representations. Visual modelling principles are regarded as modes of how to collect, organise, investigate and transform information into a visual representation. Thus, visual representation is an important component as well as a result of the visual modelling process.

\section{Structuring the Process of Visual Modelling}

The normative-based spatial planning in Latvia as well as in other European countries determines the requirements for the legally binding documentation of spatial planning. However, these legally binding norms do not determine which principles should be used to structure information and spatial proposals during the modelling process of urban planning strategies. According to the established planning traditions and in the context of the local environment, the principles of the informal 
planning process and the use of visual representation strongly differ in various European countries. When it comes to urban planning in Latvia, at present legally non-binding methodology has not been formulated either in theory or in practice as to how a visually spatial modelling can be taken forward to structure architectonic research during the informal process of planning. The case studies of urban planning practice indicate inconsistent methodological approach to informal visually spatial modelling. That is exactly why the scientific reliability and validity, as well as architectonically artistic quality and the creative approach of the research process and results can be questioned. Structuring of the visual modelling process is an important criterion to enhance quality of the research.

The author of numerous academic and policy-oriented papers in the subjects of European spatial planning and the role of cartographic representations in planning Stefanie Dühr has indicated legally binding and legally non-binding types of visual representation as a starting position for the interpretation of visual representation in urban planning [6,39-77]. This classification demonstrates two important functions of visual representation in urban planning - the normative-based illustration and architectonic modelling. These functions are the contrasting but interconnecting modes to structure information in urban planning. Legally binding visual representations are mainly thematic mappings and formal hierarchy of plans, which represent sets of legally determined graphical interpretation of territorial zoning and parameterisation of building regulations. However, binding visual representations do not reflect on the dynamic processes of urban planning - urban development trends, spatial-temporal transformations and interactions of different factors. Binding visual representations lack any evidence of architectonic research process and visually spatial argumentation for legal requirements. On the contrary, non-binding visual representations can be used in an informal way to deal with problems related to the formal framework of urban planning even as the strategy itself is modelled or used as a support and specification of legally binding documentation. Thus, non-binding visual representations is an attempt to draw closer to the methodological architectonic research and consolidated visually spatial concept of the urban planning strategy.

Architectonic research can be regarded as an essential component of informal modelling of urban planning strategies. This kind of research should be also included in legally-binding documentation. For that reason, it is important that research by design methodology is used as a framework for the research. Research by design methodology is a structured approach to arrange architectonic thought, which specifies the sequence of the process and defines the criteria and important concepts of the research evaluation. The legally-binding documentation, which is based only on formal and generalized statements, lacks this kind of clear representation of architectonic reasoning. As a result, urban planning strategies fail to demonstrate a consolidated architectonically spatial concept and structural plan, which is one of the most important criteria of the urban planning development.

Within the framework of research by design methodology, scenarios can be indicated as an important method to develop urban planning strategies. Scenarios can be seen as a tool to investigate diverse possibilities of future urban development trends and to visualize the legally binding norms, as well as architectonically modelled alternatives. The widespread use and communicative effectiveness of scenarios can be explained by concentrated formulation and explanatory argumentation of the strategic key themes in both visually direct and associative modes. Even though scenarios are based on a quantitative data research, this method is to be considered a qualitative research method [6, 59-75]. The method of scenarios as a structuring tool is especially important during the informal architectonical research, integrating both the scientific approach (objectively provable data) and the artistic approach (the subjective vision of an expert).

Two important types of scenarios can be identified, which also emphasize the normative-based illustration and architectonic modelling as two contrasting functions of visual representation in urban planning. Normative-based scenarios represent the existing urban planning development trend within legal framework, influence of the normative structure on the architectonically spatial modelling, and its possible results. In more detail, the normative-based scenarios can be classified according to their mode of inquiry as descriptive, proactive or explorative normative scenarios, as well as trend scenarios and strategic (Leitbild) scenarios. Architectonic modelling is opposed to alternative strategic scenarios, which represent desirable and possible spatial development in contrast to and comparison with the existing legal framework. Alternative scenarios are often radical and utopian, and circumstances of their implementation usually do not even exist at the moment of modelling [6,59-75]. As a consequence of those vast and flexible modelling conditions, alternative scenarios can be easily applicable to conduct architectonic research.

Spatial visions can also be recognized as the method for developing urban planning strategies, even though a strict boundary between scenarios and spatial visions is not defined. However, in contrast with scenarios, which are regarded more as normative-based, truth-reliable research methods and tools for developing a probable urban future, spatial vision emphasizes architectonic approach and development of a possible future $[6 ; 9 ; 13 ; 15]$. More precisely, spatial visions can be classified as the master plan, truth, utopia or dystopia and mission statements. Vision as a master plan represents functionally spatial comprehension of the territory over a certain period of time. Thus, a wide range of interests is summarized, and shared understanding of spatial development is demonstrated. Spatial vision as the truth most often indicates the possible negative development trend. This is to stimulate action on particular decisions. Spatial vision as utopia or dystopia represents possible idealised future situations or their contrasting opposites. Spatial vision as mission statements formulate fundamental principles of urban development (for example, sustainability of the environment or a clear process of decision taking), which should direct the following urban planning stages [6, 59-75]. According to case studies in practice of urban planning, it can be assumed that spatial vision is the most frequent type of urban planning development methods, which is used in academic environment and practice to structure architectonic research in Latvia. On the whole, scenarios and spatial visions are particular viewpoints 
or attitudes towards the key themes of urban planning as can be opposed to assumption that they just illustrate or complement a legal framework.

Based on specifics to develop urban planning strategies, two major groups of visual modelling principles can be identified - cartographic principles and architectonically artistic principles $[1 ; 3 ; 6 ; 7 ; 11 ; 15]$, which can be used as techniques to develop both scenarios and spatial visions. These principles clearly demonstrate two approaches of visualisation, in other words, the difference between visual transformations of information. Cartographic principles are an approach to structure all available information in two-dimensional representations. On the contrast, architectonically artistic principles are used to model architectonically spatial concept and spatial structural plan of the urban planning strategy.

On the basis of cartographic principles, the graphical symbol systems created by geographers Jacques Bertin and Roger Brunet are used, which represent the compliance of the visual representation with conventional temporal-spatial consciousness theories and strict methodology of cartographical representation $[3 ; 6,2-79]$. Carto-scenarios and geodesign are the derivations of cartographic principles, which are developed during the last decades. Carto-scenarios are the generalised, synthesised representations of temporary spatial dynamic relations. Geodesign is a representation of abstract and highly generalised planning aspects at the national and transnational planning level [6, 49-80]. As a principle of visual modelling, it is possible to use geodesign also in spatial visions at a local level. It can be effective mode of an abstract representation, when concentrated expression is needed to summarize and consecutively represent the main idea of the urban planning strategy. The convergence of cartographic principles, carto-scenarios, geodesign and artistic approach can be generally characterized as a diagrammatic mode of visualisation, creatively applying ideograms, pictograms, emblems, logotypes on the geographically functional base maps $[1 ; 11 ; 16]$. The result is a visual representation, which is precise both in spatial coordinates and in abstract condensation of information, allowing different directions of possible development trends.

Even though cartographic principles have not substantially changed in the recent decades, digital technologies allow structuring a vast amount of information in a relatively short period of time. Thus, multiple visualizations of the same information or combinations of different information layers based on geographically functional map can be generated, and geographical information systems and other databases can be interconnected. The process of visualisation itself has become scientific and technological allowing cartographic principles to be implemented into interactive collaboration platforms and scientific databases. Due to the digital technologies and widely accessible cross-disciplinary studies, cartographic principles in urban planning have also been transformed into a flexible artistic approach, which can be regarded as mapping [1; 11]. Mapping is also closely connected with architectonic modelling principles, thus converging architectural, sociological and philosophical assumptions. Taking into consideration that cartographical principles are widely used in other disciplines and in everyday life, it is an effective way of mutual communication during the work process and demonstration of the end result of the urban planning strategies.

The existent spatial context in Latvia can be seen as a unique interaction of situations related to the landscape and landscape architecture and their interaction. Thus, visual modelling approaches to be used in an informal planning process need to be based on the simultaneous development of urban planning, architecture and landscape architecture. The case studies and examples of this kind of modelling are visual modelling principles, which have been summarized by a State Architect of the Flemish Region 2004-2010, Professor of Architecture at the University of Leuven Marcel Smets and the Director of Delft School of Design, Professor of Architecture Ari Graafland [7; 15]. The assumptions of M. Smets and A. Graafland are based on the case studies of urban planning practice in Belgium, the Netherlands, France, Germany, and Italy. The territories of these countries, especially Belgium and the Netherlands, are characterized as the highly urbanized ones and are conceptually regarded as the uninterrupted urban structures. Nevertheless, the visual modelling principles classified by M. Smets and A. Graafland are based on the visual, architectonic landscaping approach modelling for both the urban environment in the cities and landscape $[7 ; 5 ; 15]$.

M. Smets has determined four diverse principles of visual modelling. These are principles related to the grid, casco (the landscape grid), clearing (landscapes) and montage (raster, hülse, lichtung, montage) approaches to construct conceptual spatial visions [15]. These principles also demonstrate four typical situations of spatial context or their prototypes, which determine the principle to be used. Similar approaches to visual modelling have been identified by A. Graafland - drift, layering, game-board and rhizome principles [7]. These are focused more on conceptual and ideological planning and less on spatially structural planning. These principles represent a way of organising the architectonic thought according to philosophical ideas, as well as a way of thinking about space and its physical environment in a nonspatial and cartographic way.

S. Dühr emphasizes that transition between the legally nonbinding visual modelling principles and legally binding documentation of urban planning is not a widely researched field in urban planning [6, 39-77]. Visual modelling principles are only tools to structure architectonic research and model spatial concept. They do not guarantee the transfer of the research results to the legally binding framework. However, these principles establish the position of the architect-urban planner in the interdisciplinary process and promote comprehension of urban planning strategies to an ever-wider audience. Methodologically arranged documentation can be an architectonic and scientific argumentation to be included in the legally binding structure or urban planning.

\section{Criteria to Analyse Visual Representation and Visual Modelling Principles}

Visual representation can be conceptualized by the directly seen level of formal visual means and indirect interpretation level of the meaning, as it is assumed in the theories, which interpret visual representation $[4,2-64 ; 6,1-79 ; 10,35-58 ; 14,29-40 ; 16$, $1-28]$. Those levels in visual representation in urban planning are 
highly complicated, spanning the gap between text and various systems of visual representations and consolidating them into the unified visual structure. Therefore, this unified visual structure can be considered a specific visual language, which is more descriptively conventional than analogue. The main function of visual language is defined as the precise and consecutive structuring of information by a means of the purposefully considered visual conceptualisation principles [12, 87-129]. According to the features of visual language in urban planning, several criteria to analyse visual representation and visual modelling principles can be identified. Those are presumptions of visual modelling process, sequence and prospective results of modelling procedure, scientific reliability and validity and architectonically artistic quality, interpretation of directly seen and indirect content and the logics of creation of a consolidated viewpoint.

Although the visual modelling principles are only tools for structuring architectonic research, methodological structure can enhance scientific and architectonically artistic reliability and validity. On the whole, the visual modelling principles are components of fragmented, but mutually compatible platform of technical skills, knowledge and competence, as well as a means of constructing architectonic and scientific databases. In this way, the direct connection between vision and knowledge, conceptual and materialistic approaches, different databases of visual and non-visual information, as well as between artistically creative and scientifically analytical approaches is underlined. The visual modelling principles define what type of research design can be conducted, what kind of questions can be asked and how to answer them in a determined cultural context.

The basic presumption to conduct architectonically artistic modelling is to construct a consolidated spatial concept even in the early stages of urban planning strategies under undefined, fluctuating economic conditions and social circumstances. The group of architectonically visual modelling principles is closely attached to the architectonical and geographical context of a particular territory, transforming the generalized development vision, textually defined problems, goals and possibilities, as well as cartographic information into architectonic, visually spatial concept. The sequence of procedures of the visual modelling principles can be divided into two sequential stages - the analysis of existing spatial context and modelling of future spatial context. Each principle is a conceptual prototype of how to organize and represent spatial context. This kind of visual modelling is construction of precise, yet flexible and open spatial structural plan and formulation of architectonic values, which ensure the possibility to reinforce consolidated visually spatial concept of environment and to avoid strict programmatic and architectonical requirements for separate architectonic objects.

Within the framework of the research by design methodology, visual representation functions as scientifically analytical evidence can be evaluated as an objectively verifiable, accurate, factual and truthful expert viewpoint, as well as an artistic experiment or critical opinion, which represents alternatives, new positions, procedures and unexpected solutions to the existing problem situations. Thus, visual representation as an artistic experiment is a possible and artificial construction, which cannot be evaluated only in terms of scientific reliability and validity. Artistic experiment offers a non-existent urban planning strategy as an authentic experience, which in most cases does not have any equivalent in the real everyday situations. These contradictory evaluation criteria are one of the reasons, why the principles of visual modelling are not widely used in legally binding procedures of urban planning.

The interpretation of a visual representation in urban planning is largely based on the visually spatial aesthetics $[14,35$ $49 ; 16,29-40]$, which is orientated towards the representation of the physical environment and its spatial transformations. Visually spatial aesthetics is based upon the dominating principles of the temporary spatial consciousness theories - Euclidean geometry and coordinate system of Descartes, the logics of network geometry, as well as linear perspective $[4,2-64 ; 6,43-47 ; 14$, 35-49]. The compliance of visual representation with these dominating principles is one of the criteria, which can enhance the scientific reliability and validity of the visual representation. Visually spatial aesthetics is also related to the use of the formal means of visual expression - composition of visual elements, rhythm, proportions, structure, materials, scale, light and colour. These means of expression can be equally important ways of increasing reliability in compliance with the temporary spatial theories and objective fact-based details. On the level of directly seen content, the interpretation of indirect or associative meaning has a secondary role.

The information in the visual representation in urban planning is structured in the direct way as well as in the way of associative metaphors, symbols and text [4, 2-64; 14, 74-107]. The visual representation is, therefore, largely subjected to the associative interpretation and the interpretation of the meaning, which is connected with the ways of how the information is being conceptualised. This process is generalisation and specification of the information, categorisation of visual and non-visual data and creation of the visual and textual conventions. Hence, visual representation becomes the internally interconnected and referenced system, which provides multiple and diverse representations and explanations. The visual modelling principles can be assumed as a means of structured conceptualization. The structure and coherence of the information is a criterion to increase reliability and validity as well. In this way, the indirect, associative level is mainly subjected to conventions and interpretations contained within a set of visual representation, and less subjected to generally accepted conventions that assign unstable meaning to components of visual representation.

Set of visual representations as a structuring system of information can be interpreted as a consolidated viewpoint or architectonic discourse. The consolidation allows the audience to take a defined position in relation to the represented issue, aims or possibilities and to identify itself with this viewpoint. In this context, visual representation in urban planning can be analysed similarly to a text [2,629-634], which is structured logically and has defined means of expression. Integrated use of text and visual representation is an important tool to construct a consolidated viewpoint. The structuring of this kind allows simultaneous perception of visual and non-visual information and merging it into a consolidated viewpoint. 
Even though the effectiveness of communication is difficult to evaluate, the criteria to structure and analyse visual representation and modelling allow partial forecasting of how the represented information is being perceived and whether the audience can understand it and also accept it as its own viewpoint or put forward new arguments. The visual modelling principles, as an informal and legally non-binding way of conducting architectonic research and constructing architectonically spatial concepts, are not adequately valued in the theory and practice of urban planning in Latvia at the moment. The evaluation criteria can be a framework of references for architects-urban planners to utilize the potential of contemporary visualization possibilities.

\section{REFERENCES}

1. Abrams, J., Hall P. Else/Where: Mapping New Cartographies of Networks and Territories. Minneapolis, MN: University of Minnesota Design Institute, 2006, 320 p.

2. Bal, M. Visual Narrativity. Routledge Encyclopedia of Narrative Theory. London, New York: Routledge, 2005, p. 629-633.

3. Blackwell, A. F. Diagrams about Thoughts about Thoughts about Diagrams. Reasoning with Diagrammatic Representations II: Papers from the AAAI 1997 Fall Symposium, Massachusetts Institute of Technology. [online] Cambridge, Menlo Park, California: AAAI Press, 1997. pp. 77-84. [cited 15.04.2011] http://www.cl.cam.ac.uk/users/afb21/publications/AAAI.html.

4. Bolter, J. D., Grusin, R. Remediation : Understanding New Media Cambridge: The MIT Press, 2002. 295 p.

5. Burg van den, L. Urban Analysis Guidebook : Typomorphology. Delft: DUP Science, 2004. 295 p.

6. Dühr S. The Visual Language of Spatial Planning : Exploring Cartographic Representations for Spatial Planning in Europe. London, New York: Routledge, 2007. 196 p.

7. Graafland, A. D. Understanding the Socius Through Creative Mapping Techniques. Delft: Delft School of Design, 2010. 55 p.

8. Holmes, M., Rice, A., Tomlinson, J. Will Emerging Digital Representation Tools Change our Design Judgments and Results? : A Comparison of Realities. Procedings B : Research by Design. Delft: DUP Satellite, 2001. p. 306.

9. Jong de, T. M., Voordt van der, D. J. M. Ways to Study and Research Urban, Architectural and Tecnical Design. Delft: DUP Science, 2002. 554 p.

10. Mitchell, W. J. T. Iconology : Image, Text, Ideology. Chicago and London: The University of Chicago Press, 1987. 226 p.

11. Monmonier, M. How to Lie with Maps. Chicago, London: The University of Chicago Press, 1991. 176 p.

12. Narayanan, N. H., Hübscher, R. Visual Language Theory : Towards a Human-Computer Interaction Perspective. Visual Language Theory. New York: Springer, 1998, p. 87-129.

13. Reed, S. Research and Design. Procedings $B$ : Research by Design. Delft: DUP Satellite, 2001, p. 262-268.

14. Rose, G. Visual Methodologies : An Introduction to the Interpretation of Visual materials. London: Sage Publications, 2007. 304 p.

15. Smets, M. Raster, Hülse, Lichtung und Montage = Grid, Casco, Clearing and Montage. Texte zur Landschaft : Essays über Entwurf, Stil, Zeit und Raum = About landscape : Essays on Design, Style, Time and Space. München: Callwey Verlag, 2002,p. 88-101.

16. Somol, R. E. Green Dots 101. Rethinking Representation : The Berlage Institute Report No.11. Rotterdam: Episode Publishers, 2007, p. 29-40.

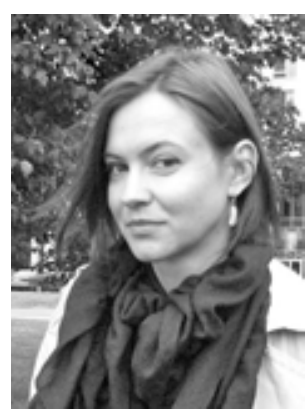

Ilze Paklone, Architect (RTU, 2005), Mag. arch. (2008), specializes in urban planning. Ilze Paklone is currently the third year student of the doctoral program "Architecture" at Riga Technical University in Latvia, thesis "Visual Representation in Contemporary Urban Planning".

Tutor at the International Summer Schools organized by Riga Technical University: workshop "Urban Forest Narrative" (2008) in collaboration with the architect Alise Plavina (Latvia), workshop "Border Sense" (2009) and workshop "Space Merchants" (2010, together with the architect Ryan Manton, $\mathrm{UK})$.

ARCHITECT, worked at several architectural offices in Riga (Velve-AE, Armands Bisenieks Arhitekti, NRJA).

Extended international professional experience by participating in EC Learning Programme Leonardo and working for nine months as a trainee (2008), and one year as an architect (2009) at Wiel Arets Architects in the Netherlands.

\section{Contact Data}

Ilze Paklone

Riga Technical University, Faculty of Architecture and Urban Planning Address: Āzenes iela 16, Riga, LV-1048, Latvia

Phone: +37129176181

E-mail: ilze.paklone@inbox.lv 
Ilze Paklone. Pilsētplānošanas vizuālās modelēšanas principi

Rakstā sistematizētas pilsētplānošanas pētījumu atziṇas, kas akcentē vizuālo modelēšanas principu nozīmi likumiski nesaistošajā pilsētplānošanas stratēǵiju formulěšanas un komunicēšanas procesā. Raksta mērkis ir koncentrēti apkopot nozīmīgākos vizuālās modelēšanas principus un ar tiem saistītos jēdzienus, kā arī vizuāla attēlojuma tipus, funkcijas un analīzes kritērijus. Likumiski saistošie un likumiski nesaistošie vizuālie attēlojuma tipi pilsētplānošanā izdalīti, lai akcentētu divas nozīmīgas vizuālā attēlojuma funkcijas pilsēptlānošanā - normatīvi ilustrējošo un arhitektoniski modelējošo. Kā pilsētplānošanas stratēǵiju modelēšanas metodes izdalīiti scenāriji un telpiskie priekšlikumi, kas veido konceptuālu ietvaru likumiski nesaistošajiem vizuālās modelēšanas principiem. Scenāriju un telpisko att̄̄stības priekšlikumu modelēšanai apkopoti vairāki vizuālās modelēšanas principi pēc veida, kā strukturēt informāciju vizuālā veidā - kartogrāfiskie un arhitektoniski mākslinieciskie principi. Vizuālās modelēšanas principi ir savstarpēji savietojama tehnisku iemanu, zināšanu un kompetenču platforma, kā arī arhitektonisku un zinātnisku datu bāzu konstruēšanas metode. Vizuālā attēlojuma un vizuālo analīzes principu analīzei apkopoti vairāki kritēriji, balstoties uz veidiem, kā tiek uztverts un dekodēts vizuāls attēlojums. Analīzes kritēriji dạ̣̄eji ḷauj prognozēt, vai auditorija spēj informāciju saprast un pieṇemt arī kā savu skatpunktu. Apkopotie vizuālās modelēšanas principi var tikt pielietoti Latvijas pilsētplānošanas praksē likumiski nesaistošajā informācijas strukturěšanas procesā un stratẹǵiju komunicēšanā.

\section{Илзе Паклоне. Принципы визуального моделирования градостроительства}

В статье систематизированы выводы исследований градостроительства, которые акцентируют значение принципов визуального моделирования в процессе юридически несвязанного моделирования и коммуникации стратегий планировки города. Цель статьи - концентрированно обобщить важнейшие принципь визуального моделирования и связанных с ними понятий, а также типы визуального отображения, функции и критерии анализа. Юридически связанные и несвязанные типы визуального отображения в планировке города выделены, чтобы акцентировать две важные функции визуального отображения в планировке города - нормативно-иллюстрирующую и архитектурно-моделирующую. В качестве методов моделирования стратегий планировки города выделены сценарии и пространственные предложения, которые создают концептуальное руководство к юридически несвязанным принципам визуального моделирования. Для моделирования сценариев и предложений пространственного развития обобщены несколько принципов визуального моделирования по способу структурирования информации в визуальном виде. Это - картографические и архитектурно-художественные принципы. Принципы визуального моделирования - это взаимосвязанная платформа технических навыков, знаний и компетенций, а также метод конструирования архитектурных и научных баз данных. Для анализа принципов визуального отображения и визуального анализа обобщено несколько критериев, основываясь на видах восприятия и декодирования визуального отображения. Анализ критериев дает возможность частично прогнозировать понятие и восприятие информации аудиторией как свою точку зрения. Обобщенные принципы визуального моделирования могут быть использованы на практике в латвийском градостроительстве в юридически несвязанном процессе структурирования информации и коммуникации стратегий. 


\title{
Pilsētplānošanas vizuālās modelēšanas principi
}

\author{
Ilze Paklone, Rīgas Tehniskā universitāte
}

ATSLĒGAS VĀRDI: vizuālās reprezentācijas funkcijas, scenāriji, telpiskās vīzijas, vizuālās reprezentācijas tipi, pilsētplānošana, vizuālās modelēšanas principi.

21. gadsimta sākumā pilsētplānošana ir transformējusies par atklātu un interdisciplināru procesu. Tā vairs nav tikai arhitektupilsētplānotāju un citu plānošanas procesā iesaistīto ekspertu noslēgta disciplīna. Šis aspekts ir izaicinājums arhitektiempilsētplānotājiem vizuāli modelēt pilsētplānošanas stratēǵijas tā, lai tās būtu pieejamas un saprotamas ne tikai profesionālu arhitektu un plānotāju, bet arī neekspertu auditorijai - galvenajiem sabiedriski nozīmīgo lēmumu pienēēējiem. Pilsētplānošanas vizuālo jautājumu speciālists Peters Molls (Peter Moll) akcentē,ka vizuāla attēlojuma izmantošanai pilsētplānošanā ir nepieciešamas divu tipu kompetences - saprast un attēlot reālo, telpisko sarežg̀îtîbu vienlaicīgi ar iespējamo realitāti un pilsētplānošanas stratēǵijas sekām, kā arī attīstīt komunikācijas iemanas, lai jau darba procesā vienotos par nozīmīgiem lēmumiem starp dažādiem iesaistītiem dalībniekiem [6, 58]. Vizuāls attēlojums vienmēr ir bijis primārais izteiksmes līdzeklis gan arhitektūrā, gan pilsētplānošanā. Tehnoloğiskās iespējas, starpdisciplinārā sadarbība un pilsētplānošanā nozīmīgo tēmu maiṇa pēdējās desmitgadēs ir bijis jaunu, iepriekš neparedzētu vizualizēšanas veidu un esošo vizualizēšanas principu uzlabošanas iespēju cēlonis $[2 ; 4 ; 6 ; 9 ; 10 ; 14 ; 15 ; 16]$.

2001. gadā „Kseroks” izpētes centra Palo Alto vadītājs Džons Sīlijs Brauns (John Seely Brown, Xerox Palo Alto Research Center) ir akcentējis, ka zinātnes attīstību virza nevis teorija, bet instrumenti, jo tie ir pilnīgi mainījuši inovāciju ātrumu un veicamo pētījumu raksturu, nosakot, kādus jautājumus var uzdot un kā uz tiem var atbildēt [8, 306]. Savukārt zinātnē izmantoto vizuālo attēlu pētniece Barbara Marija Staforda (Barbara Maria Stafford), uzskata, ka zinātnisku datu bāzu un zināšanu konstruēšana 21. gadsimta sākumā arvien vairāk kḷūst balstīta uz vizuālu attēlojumu kā zinātnisku pierādījumu un analītisku izpētes instrumentu [14, 5]. Starpdisciplināros pētījumos vizuāls attēlojums tiek pakḷauts galvenokārt vizuāli estētiskai un semiotiskai analīzei. Pilsētplānošanā vizuāls attēlojums ir modelēšanas instruments, kas parāda informācijas strukturēšanas veidu un lauj sekot līdzi arhitektoniskās domas attīstībai. Tāpēc vizuālo aspektu izpēte pilsētplānošanā balstīta gan starpdisciplināros, gan pilsētplānošanas teorijas apsvērumos un pilsētplānošanas prakses vizuālās dokumentācijas piemēru analīzē. Pēdējo desmitgažu izpētes metodologíju tendences iezīmē centienus apvienot māksliniecisku un zinātniski analītisku pieeju vizuālajā modelēšanā gan mākslas disciplīnās, gan arhitektūrā un pilsētplānošanā. Šāda integrēta izpēte tiek dēvēta par arhitektoniski modelējošu metodolog̣iju (research by design methodology) [9, 6-19].

Mākslinieciskas un zinātniski analītiskas pieejas apvienojums ir ietvars arī vizuāla attēlojuma analīzei un vizuālās modelēšanas principiem, kuri pozicionē vizuālu attēlojumu ne tikai kā esošās vai nākotnes situācijas tiešu vai asociatīvu attēlojumu, bet galvenokārt kā vizuālas analīzes principu, zinātnisku dokumentu un māksliniecisku darbu vienlaicīgi. Šāda pieeja saitīta ar principiem, kā modelēt vizuāli - kā strukturēt informāciju un $k \bar{a}$ modelēt jaunas iespējas. Vizuālās modelēšanas principi var būt viens no instrumentiem, kā pilsētplānošanas stratēǵijas jau neformālā, likumiski nesaistošā procesā modelēt kā arhitektoniski telpiskas koncepcijas un telpisku argumentāciju likumiski saistošajiem pilsētplānošanas dokumentiem tematiskajiem kartējumiem un parametrizētiem apbūves noteikumiem. Šāda arhitektoniski telpiska argumentācija, nevis vispārīgi attīstības mērki, var būt saprotama gan ekspertu, gan neekspertu auditorijai.

Raksta mērkis ir sistematizēt nozīmīgākos vizuālās modelēšanas principus, kurus var izmantot pilsētplānošanas stratēǵiju formulēšanas darba procesā to arhitektoniski telpiskā argumentēšanā un izskaidrošanā. Pamatuzdevumi, ko šāds darba mērkis izvirza, ir klasificēt nozīmīgākos vizuālā attēlojuma tipus, funkcijas un pilsētplānošanas stratēǵiju attīstīšanas metodes, kā arī vizuālā attēlojuma un vizuālo modelēšanas principu analīzes kritērijus. Šāda pieeja ir esošo vizuālās modelēšanas principu integrēšanas iespēju meklējumi.

Rakstā tiek lietos jēdziens vizuāls attēlojums, lai ieviestu skaidru nodalījumu starp pašu vizuālo attēlojumu (kaut $k \bar{a}$ reprezentāciju, attēlojumu) (visual representation, visualisation, visual image) un ideju, koncepciju, stratēǵiju, tēlu (idea, notion, conception, strategy, image). Vizuāls attēlojums pilsētplānošanā šajā rakstā tiek pien,emts gan kā kāds atsevišks attēlojums, gan var tikt interpretēts kā komplekss attēlojumu kopums. Vizuālās modelēšanas principi savukārt ir veids, kā vākt, organizēt, pētīt un transformēt informāciju vizuālā attēlojumā. Vizuāls attēlojums šajā kontekstā ir nozīmīga vizuālo modelēšanas principu sastāvdaḷa un modelēšanas procesa rezultāts.

\section{VIZUĀLĀS MODELĒŠANAS PROCESA STRUKTURĒŠANA}

Latvijas un arī citu Eiropas valstu normatīvi nosaka prasības telpiskās plānošanas likumiski saistošajam galarezultātam, taču nenosaka, pēc kādiem principiem strukturējama informācija neformālajā pilsētplānošanas stratēǵiju modelēšanas gaitā. Neformālā plānošanas procesa principi un vizuāla attēlojuma izmantošana dažādās Eiropas valstīs atškiras atkarībā no iedibinātajām plānošanās tradīcijām un vietējā vides konteksta. Latvijas pilsētplānošanas teorijā un praksē šobrīd nav sakārtotas likumiski nesaistošas vizuālās modelēšanas principu izmantošanas metodoloğijas, kā veikt vizuāli telpisku, arhitektonisku izpēti neformālā plānošanas procesā. Praktiskā pieredze liecina, ka šādas izpētes bieži tiek veiktas metodoloǵiski nekonsekventi. Tas liek apšaubīt izpētes procesa un rezultātu zinātnisko līmeni, uzticamību un izmantojamību, kā arī arhitektoniski māksliniecisko kvalitāti un radošo pieeju. Vizuālās modelēšanas procesa struktūras sakārtošana ir būtisks kritērijs, lai tiktu nodrošināta izpētes kvalitāte. 
Vairāku ar telpiskās plānošanas politiku saistītu pētījumu autore Stefānija Dīra (Stefanie Dühr) izdalījusi likumiski saistošos un likumiski nesaistošos vizuālā attēlojuma tipus kā sākuma pozīciju vizuāla attēlojuma interpretēšanai pilsētplānošanā [6, 39-77]. Šāda klasifikācija norāda uz normatīvi ilustrējošo un arhitektoniski modelējošo vizuālā attēlojuma funkciju pilsētplānošanā. Tie ir atškirīgi, taču savstarpēji saistīti informācijas strukturēšanas veidi. Likumiski saistošie vizuālie attēlojumi galvenokārt ir tematiski kartējumi, kas vizuāli interpretē likumiski noteikto teritorijas izmantošanas zonējumu un apbūves noteikumus. Tomēr likumiski saistošie vizuālie attēlojumi neatspoguḷo pilsētplānošanas dinamiskos procesus - attīstības virzienus, kā arī telpas izmainas un dažādu faktoru mijiedarbību laikā. Likumiski saistošie vizuālie attēlojumi neietver arī arhitektoniski telpisku izpēti kā argumentāciju telpiskās plānošanas likumiskajam ietvaram. Savukārt likumiski nesaistošie vizuālie attēlojumi var būt veids, kā arhitektoniski telpiski argumentēt pilsētplānošanas stratēǵijas to modelēšanas procesā vai pamatot un detalizēt likumiski saistošos vizuālos attēlojumus. Ar šādu attēlojumu palīdzību var veikt metodoloğisku arhitektoniski telpisku izpēti un vienotas telpiskas koncepcijas modelēšanu.

Var uzskatīt, ka arhitektoniska izpēte ir būtiska neformālā pilsētplānošanas stratēǵiju modelēšanas sastāvdaḷ. Tai būtu jābūt arīlikumiski saistošās dokumentācijas sastāvā. Lai šāda izpēte būtu zinātniski un arhitektoniski pamatota, tai jāiekḷaujas arhitektoniski modelējoša pētījuma (research by design) metodoloǵijā. Tā ir pārskatāma arhitektoniskas domas sakārtošanas sistēma, kas precizē procesa secību un formulē pētījuma novērtējuma kritērijus un nozīmīgus jēdzienus. Likumiski saistošajai dokumentācijai, kas tiek balstīta tikai formālu un vispārinātu uzstādījumu kopumā, trūkst arhitektoniskas domas atainojuma un rezultātā arī pilsētplānošanas stratēǵiju telpiskās koncepcijas un telpiskā struktūrplāna.

Arhitektoniski modelējoša pētījuma ietvaros var izdalīt nozīmīgu pilsētplānošanas stratēg̣iju attīstīšanas metodi scenārijus (scenarios). Tos var uzskatīt par instrumentiem, ar kuriem pētīt dažādus nākotnes iespēju attīstības virzienus un vizualizēt gan likumiski saistošas normas, gan arhitektoniski modelējošas alternatīvas. Scenāriju izmantošanas popularitāte un komunikatīvā efektivitāte saistīta ar stratēǵisko jautājumu koncentrētu un izskaidrojoši argumentētu formulēšanu un attēlošanu kā tiešā, tā asociatīvā veidā. Lai gan balstīti uz kvantitatīvu datu izpēti, scenāriji uzskatāmi par kvalitatīvo izpētes metodi, [6, 59-75]. Scenāriju metode kā strukturējošs instruments ir nozīmīgāka tieši likumiski nesaistošajā izpētē, integrējot gan zinātnisku pieeju (objektīvi pārbaudāmus datus), gan ar̄̄ māksliniecisku pieeju (eksperta subjektīvo redzējumu).

Scenāriji vispārīgi tiek iedalīti divos nozīmīgos tipos, kuri vēlreiz akcentē normatīvi ilustrējošo un arhitektoniski modelējošo vizuāla attēlojuma funkciju pilsētplānošanā. Normatīvi ilustrējošie scenāriji parāda esošo attīstības virzienu un esošā attīstības virziena normatīvu turpinājumu, kā arī normatīvu ietekmi uz arhitektoniski telpisko modelēšanu. Normatīvi ilustrējošos scenārijus var detalizētāk klasificēt atbilstoši to izpētes ievirzei kā aprakstošos, paredzošos vai pētošos (descriptive, proactive or explorative normative scenarios), virzienu (trend scenarios) vai stratēgiskos (Leitbild, strategy scenarios) scenāriju tipus.
Arhitektoniski modelējošie scenāriji tiek pretstatīti kā alternatīvas stratēgiskas izpētes (alternative strategic scenarios), kas parāda vēlamo un iespējamo telpisko attīstību salīdzinājumā ar esošo vai normatīvos noteikto situāciju. Alternatīvie scenāriji bieži ir radikāli un utopiski un to realizēšanas nosacījumi modelēšanas brīdī parasti vēl neeksistē [6, 59-75]. Pateicoties šiem elastīgajiem modelēšanas nosacījumiem, alternatīvie scenāriji ir viegli pielāgojami dažāāām arhitektoniskām izpētēm.

Telpiskie priekšlikumi (spatial visions) tiek izdalīti kā vēl viena pilsētplānošanas stratēǵiju attīstīšanas metode, lai gan strikta robeža starp scenārijiem un telpiskajiem priekšlikumiem netiek definēta. Pretstatā scenārijiem, kas vairāk tiek raksturoti kā normatīiva, faktoloğiski pārbaudāma un pamatota (truth-reliable, valid) izpētes metode un instruments paredzamas nākotnes (probable future) situācijas modelēšanai, telpiskie priekšlikumi akcentē vizuālu, arhitektonisku pieeju un iespējamas nākotnes (posiible future) situācijas modelēšanai $[6 ; 9 ; 13 ; 15]$. Telpiskos priekšlikumus var iedalīt ǵenerālplāna priekšlikumos (vision as master plan), telpiskos priekšlikumos kā patiesos redzējumos (vision as truth), telpiskos priekšlikumos kā utopijā vai distopijās (vision as utopia or dystopia) un telpiskos priekšlikumos kā mērku pozicionēšanā (vision as mission statement). Ģenerālplāna priekšlikums parāda funkcionāli telpisku priekšstatu par teritoriju noteiktā laika periodā un ietver plašu interešu spektru, tādā veidā demonstrējot kolektīvo viedokli par telpisko attīstību. Telpisks priekšlikums kā patiess redzējums visbiežāk parāda iespējamo negatīvo attīstības virzienu, lai stimulētu pienemt noteiktus lēmumus. Telpisks priekšlikums kā utopija vai distopija parāda iespējamās idealizētās nākotnes situācijas vai arī to pretējās ainas. Telpisks priekšlikums kā mērku pozicionēšana formulē fundamentālus attīstības principus (piemēram, vides ilgtspējība vai pārskatāms lēmumu pien,emšanas process), kam būtu jāregulē tālāka teritorijas plānošana [6, 59-75]. Praktiskā pieredze liecina, ka telpiskie priekšlikumi ir visbiežāk izmantotā pilsētplānošanas stratēéiju attīstīšanas metode gan akadēmiskā vidē, gan praktiskajā pilsētplānošanā Latvijāa Kopumā scenārijus un telpiskos priekšlikumus var uzskatīt par noteikta arhitektoniska skatījuma jeb attieksmes formulēšanu un eksperta subjektīvu skatîjumu, nevis likumisko ietvaru papildinošu ilustrāciju.

Balstoties uz pilsētplānošanas stratēǵiju attīstǐšanas metožu specifiku, var izdalīt divas nozīmīgas vizuālās modelēšanas principu grupas - kartogrāfiskie principi un arhitektoniski mākslinieciskie principi $[1 ; 3 ; 6 ; 7 ; 11 ; 15]$, ko izmanto gan scenāriju, gan telpisko priekšlikumu modelēšanā. Tie uzskatāmi parāda divas vizualizēšanas pieejas. Ar kartogrāfiskajiem principiem vizuāli tiek strukturēta visa pieejamā informācija pārskatāmu divdimensionālu plānu veidā. Savukārt ar arhitektoniski mākslinieciskajiem principiem tiek modelēta arhitektoniski telpiskā koncepcija un pilsētplānošanas stratēǵijas telpiskais struktūrplāns.

Kartogrāfisko principu pamatā tiek lietotas ǵeogrāfu Žaka Bertēna (Jacques Bertin) un Rodžera Brin̄̄ (Roger Brunet) izveidotās grafisko simbolu sistēmas, kas reprezentē vizuālā attēlojuma atbilstību vispārpieñemtajām telpas uztveres un attēlošanas koncepcijām un ir pakḷautas stingrai kartogrāfisko simbolu attēlošanas metodoloǵijai [3; 6, 2-79]. Kartoscenāriji un ǵeodizains (carto-scenarios, geodesign) ir pēdējo desmitgažu 
kartogrāfisko principu atvasinājumi. Kartoscenāriji ir vispārināti, sintezēti telpas un laika, kā arī dinamisko attiecību atainojumi. G̣eodizains ir veids, lai attēlotu abstraktus un vispārinātus plānošanas aspektus nacionālā un transnacionālā līmenī [6, 4980]. G̣eodizainu kā vizuālās modelēšanas principu iespējams piemērot arī vietēja līmena telpiskos priekšlikumos. Tas ir efektīvs princips gadījumos, kad nepieciešama abstrakta un koncentrēta izteiksme, kas apkopo un secīgi attēlo pilsētplānošanas stratēǵijas galveno domu. Kartogrāfisko principu, kartoscenāriju, ğeodizaina māksliniecisko pan̄ēmienu integrēšanu var raksturot $k \bar{a}$ diagrammatisku vizualizēšanas pieeju, mākslinieciski izmantojot ideogrammas, piktogrammas, emblēmas, logotipus uz ǵgeogrāfiski funkcionālām bāzes kartēm $[1 ; 11 ; 16]$. Šādas modelēšanas rezultāts ir vizuāls attēlojums, kas ir gan precīzs koordinātēs, gan nenoteikts un vispārināts, pielaujot dažādas attīstī̌̌anas iespējas.

Lai gan kartogrāfiskie attēlošanas principi būtiski nav mainījušies pēdējās desmitgadēs, digitālās tehnoloǵijas lauj strukturēt un vizualizēt apjomīgu informācijas daudzumu relatīvi īsā laikā. Šādi tiek ǵgenerētas vairākkārtējas vizualizācijas vienai un tai pašai informācijai, dažādu informāciju slāṇu kombinācijas ar ǵeogrāfisku piesaisti, un ǵeogrāfiskās informācijas sistēmas datu un citu datu bāzu salīdzinājumi. Pats vizualizēšanas process kluvis zinātnisks un tehnoloğisks, laujot kartogrāfiskos principus izmantot interaktīvu sadarbības platformu un zinātnisku datu bāzu veidā. Pateicoties digitālajām tehnoloğijām un starpdisciplinārajiem pētījumiem, kartogrāfiskie vizualizēšanas veidi pilsētplānošanā daḷēji transformējušie arī brīvā, mākslinieciskā pieejā, ko visaptveroši var dēvēt par kartēšanu (mapping) [1; 11]. Kartēšana ir saistīta arī ar arhitektoniski modelējošiem principiem, integrējot gan arhitektūras, gan socioloğijas, gan filozofijas atziṇas. Nemot vērā, ka kartogrāfiskie principi tiek plaši lietoti arī citās disciplīnās un ikdienā, tas ir efektīvs savstarpējas komunikācijas veids gan darba procesā, gan parādot pilsētplānošanas stratēǵiju galarezultātu.

Latvijas telpisko kontekstu var raksturot galvenokārt kā arhitektonisku ainavu telpu. Tādējādi Latvijas pilsētplānošanas situācijai nepieciešami vizuālās modelēšanas principi, kas balstīti ainavas un pilsētvides integrētā attīstīšanā. Šādas pieejas piemēri ir vizuālās modelēšanas principi, ko apkopojis Beḷ̂́ijas Flāmu reǵiona arhitekts (no 2004. gada līdz 2010. gadam), Lēvenes Katolu universitātes arhitektūras profesors Marsels Smetss (Marcel Smets, State Architect of the Flemish Region 2004-2010, Professor of Architecture at the University of Leuven) un Delftas Dizaina skolas direktors, sarhitektūras profesors Āri Grāflands (Ari Graafland, Director of Delft School of Design, Professor of Architecture) [7; 15]. M. Smetsa un Ā. Grāflanda pien̄ēmumi balstīti Beḷgijas, Nīderlandes, Francijas, Vācijas un Itālijas pilsētplānošanas prakses piemēros. Šo valstu teritorijām, seviški Beḷgijai un Nīderlandei, raksturīga loti augsta urbanizācijas pakāpe, un konceptuālājās pilsētplānošanas nostādnēs tās pienemts uzskatīts par gandrīz nepārtrauktu vienotu urbānu sistēmu. Tomēr M. Smetsa un Ā. Grāflanda klasificētie vizuālās modelēšanas principi balstīti galvenokārt arhitektoniski ainaviskā pieejā gan pilsētvides, gan ainavas telpiskā modelēšanā $[7 ; 5 ; 15]$.

M. Smetss ir izdalījis četrus vizuālās modelēšanas principus - tīkla, iekḷāvumu, noškīruma un montāžas metodes (grid, casco, clearing, montage; vāc. Raster, Hülse, Lichtung, Montage). Tie ir četri atškirīgi principi, ar kuriem vizuāli attīstīt konceptuālus telpiskos scenārijus [15]. Šie principi parāda arī četras raksturīgas telpiskā konteksta situācijas, no kurām atkarīga izmantojamā principa izvēle. A. Grāflands arī ir izdalījis četrus līdzīgus vizuālās modelēšanas principus novirzī̌sanās, slāṇošanas, spēles un rizomas pieejas (dérive vai drift, layering, game-board, rhizome) [7]. Ar šiem principiem tiek modelēts telpiskās koncepcijas idejiskais ietvars, mazāk telpiski strukturālais veidols. A. Grāflanda izvirzītie principi ir filozofisks arhitektoniskas domāšanas strukturēšanas veids, kas vairāk saistīts ar kartogrāfisko principu izmantošanu vietas konteksta interpretēšanā.

S. Dīra akcentē, ka likumiski nesaistošo vizuālās modelēšanas principu saikne ar likumiski saistošo pilsētplānošanas dokumentāciju ir maz pētīts pilsētplānošanas lauks [6, 39 -77]. Vizuālās modelēšanas principi ir tikai instruments, kā veikt arhitektonisku izpēti un modelēt telpisku koncepciju. Tie negarantē izpētes rezultātu pārnešanu likumiski saistošajos dokumentos. Vizuālās modelēšanas principi vairāk akcentē arhitekta-pilsētplānotāja līdzdalības pozīciju starpdisciplinārajā pilsētplānošanas procesā un palīdz padarīt saprotamas pilsētplānošanas stratēg̣ijas. Metodoloğiski sakārtota izpētes vizuālo attēlojumu dokumentācija var būt nozīmīga zinātniski un arhitektoniski pamatota argumentācija, lai izpētes slēdzienu iekḷautu likumiski saistošajā pilsētplānošanas ietvarā.

\section{VizuĀLĀ ATTĒLOJUMA UN VIZUĀLĀS MODELĒšAnAS PRINCIPU} ANALİZES KRITĒRIJI

Vizuāls attēlojums, kā tiek uzsvērts vizuālu attēlojumu interpretējošās teorijās $[4,2-64 ; 6,1-79 ; 10,35-58 ; 14,29-40$; $16,1-28]$, ietver gan tieši uztveramu formālās izteiksmes līdzekḷu līmeni, gan netiešu, attēlotās informācijas nozīmes interpretācijas līmeni. Vizuālā attēlojumā pilsētplānošanā šie līmeṇi komplicēti, integrējot gan tekstu, gan dažādu vizuālo attēlojumu sistēmas vienotā vizuālā struktūrā. Tāpēc vizuālo attēlojumu un vizuālās modelēšanas principu kopumu pilsētplānošanā var uzskatīt par specifisku vizuālo valodu, kas vairāk ir apzīmējoša nekā analoga. Vizuālo valodu galvenā funkcija ir precīzi un secīgi strukturēt informāciju, mērktiecīgi izvēloties vizuālās konceptualizēšanas principus [12, 87-129]. Atbilstoši šādai vizuālās valodas pilsētplānošanā specifikai, var sistematizēt vairākus vizuāla attēlojuma un vizuālas modelēšanas analīzes kritērijus. Galvenie no tiem ir - vizuālā modelēšanas procesa galvenie pamatpien̄ēmumi, darbību secība un paredzamie rezultāti, modelēšanas zinātniska uzticamība un pārbaudāmība, vizuālā attēlojumā tieši redzamā satura un nozīmes līmeṇu interpretācija, kā arī konsolidēta stāstījuma veidošanās loǵika.

Lai gan vizuālās modelēšanas principi ir tikai instruments, kas lauj vizuālā veidā sakārtot arhitektonisku domu, izpētes procesa un tā rezultātu metodoloğiska strukturēšana nodrošina arhitektoniskas modelēšanas māksliniecisku un zinātnisku pamatotību un uzticamību. Kopumā vizuālās modelēšanas principi ir fragmentāra, tomēr savstarpēji savietojama tehnisku iemanu, zināšanu un kompetenču platforma, kā arī arhitektonisku un zinātnisku datu bāžu konstruēšanas metode. Šādi tiek akcentēta saikne starp redzēšanu un zināšanām, konceptuālo un 
materālo pieeju, dažādām vizuālas un nevizuālas informācijas datu bāzēm un radošo un zinātniski analītisko pieeju. Vizuālās modelēšanas principi nosaka, kāda rakstura pētījums var tikt veikts, kādi jautājumi uzdoti un kā uz tiem atbildēt noteiktā kultūras kontekstā.

Viens no vizuālās modelēšanas principu galvenajiem pamatpien̄ēmumiem ir telpiskas koncepcijas formulēšana nenoteiktos, svārstīgos ekonomikas un sabiedrisko procesu apstākḷos jau pilsētplānošanas stratēǵiju formulēšanas darba procesā. Tikpat nozīmīgs pamatpienēēmums ir modelēšanas balstīšana katras vietas īpašajā ǵeogrāfijas, arhitektūras un ainaviskajā kontekstā, vizuāli telpiskā koncepcijā transformējot vispārīgo, tekstuāli formulēto problemātiku, mērkus, iespējas, kā arī kartogrāfisko informāciju.Vizuālo modelēšanas principu darbību secību var sadalīt divos nozīmīgos posmos - esošā telpiskā konteksta analīze un nākotnes telpiskā konteksta modelēšana. Katrs vizuālās modelēšanas princips ir konceptuāls prototips kā organizēt un attēlot telpisko kontekstu. Šāda modelēšana ir noteikta, tomēr elastīga un atvērta telpiskā struktūrplāna radīšana un arhitektonisko vērtību formulěšana, kas nodrošina iespēju saglabāt vienotu vides veidolu un izvairīties no striktām programmatiskām un arhitektoniskām prasībām atseviškiem arhitektūras objektiem.

Arhitektoniski modelējoša pētījuma kontekstā vizuāls attēlojums funkcionē gan kā zinātniski analītisks pierādījums, ko var izvērtēt kā objektīvi pārbaudāmu, precīzu, faktisku un patiesu eksperta skatījumu (valid, verifiable, objective, accurate, factual, truthful), gan kā māksliniecisks eksperiments vai kritisks piedāvājums, parādot alternatīvas, jaunas pozīcijas un procedūras un negaidītus risinājumus esošajās problēmsituācijās. Šāds vizuāls attēlojums ir iespējama, mākslīga konstrukcija, ko nav iespējams izvērtēt tikai kā zinātniski patiesu un pārbaudāmu. Māksliniecisks eksperiments piedāvā vēl neeksistējošu pilsētplānošanas stratēǵiju kā autentisku pieredzi, kam visbiežāk nav ekvivalenta ikdienas reālajās situācijās. Šādi pretrunīgi izvērtēšanas kritēriji ir viens no cēloniem, kāpēc vizuālās modelēšanas principi netiek iekḷauti likumiski noteiktās pilsētplānošanas procedūrās.

Vizuāla attēlojuma pilsētplānošanā interpretācija lielā mērā balstīta uz tieši redzamo vizuāli telpisko estētiku $[14,35$ $49 ; 16,29-40$ ], kas orientēta uz fiziskas vides un tās telpisko transformāciju atainošanu. Vizuāli telpiskā estētika ir balstīta dominējošajos telpas un laika organizācijas principos - Eiklīda ǵeometrijā un Dekarta koordinātu sistēmā, tīkla ǵeometrijas loğikā, kā arī lineārajā perspektīvē [4, 2-64; 6, 43-47; 14, 35-49]. Vizuāla attēlojuma atbilstība šiem dominējošajiem principiem ir viens no kritērijiem, kas var veicināt vizuāla attēlojuma zinātnisku uzticamību un pārbaudāmību. Vizuāli telpiskā estētika saistīta arī ar vizuāli formālo izteiksmes līdzekḷu izmantošanu - vizuālo elementu kompozīciju, ritmu, proporcijām, struktūru, materiāliem, mērogu, gaismu un krāsu. Šie izteiksmes līdzekḷi var būt tikpat nozīmīgi uzticamību rosinoši kritēriji kā atbilstî̉ba priekšstatiem par laika un telpas attēlošanu vai objektīvi faktoloğiskām detalām. Tieši uztveramajā vizuālajā līmenī netiešai nozīmes vai asociatīvai intepretācijai ir sekundāra loma.

Informācija vizuālā attēlojumā pilsētplānošanā tiek strukturēta gan tiešā, gan asociatīvu metaforu, simbolu un teksta veidā [4, 2-64; 14, 74-107]. Tāpēc vizuāls attēlojums lielā mērā paklauts asociatīvai un nozīmes interpretācijai. Vizuāla attēlojuma pilsētplānošanā interpretācija saistīta ar izpratni par veidiem, kā tiek konceptualizēta informācija. Šis process ir informācijas vispārināšana vai detalizēšana, vizuālu un nevizuālu datu kategorizēšana un apzīmējumu veidošana. Tādējādi vizuāls attēlojums pilsētplānošanā kḷūst par savstarpēji referencētu un pārskatāmu sistēmu, kas sniedz vairākkārtēju un dažādu informācijas atainojumu un paskaidrojumu. Vizuālās modelēšanas principus var uzskatīt par šādiem sakārtotiem konceptualizēšanas veidiem. Vizuālā attēlojumā ietvertās informācijas sakārtotība un pārskatāmība ir vēl viens zinātnisku un māksliniecisku uzticamību rosinošs kritērijs. Šādā veidā arī asociatīvais līmenis ir paklauts galvenokārt vizuālajā attēlojumā ietvertajiem apzīmējumiem un mazāk vispārpieṇemtajiem, nepastāvīgajiem pien̄ēmumiem par vizuālo elementu nozīmi.

Vizuāls attēlojums kā sakārtota un pārskatāma informācijas strukturēšanas sistēma var tikt interpretēta kā konsolidēts, nepārtraukts stāstījums jeb arhitektonisks diskurss. Stāstījuma nepārtrauktība l,auj auditorijai uztvert noteiktu pozīciju attiecībā pret attēloto problemātiku, mērkiem vai iespējām un identificēties ar šo skatpunktu. Šajā kontekstā vizuāls attēlojums pilsētplānošanā var tikt analizēts arī līdzīgi tekstam [2, 629634], kas tiek strukturēts skaidrā secībā un izmantojot noteiktus izteiksmes līdzekḷus. Stāstījuma strukturēšanā liela nozīme ir gan teksta, gan vizuālā attēlojuma integrētam lietojumam. Šāda informācijas strukturēšana pielauj gan vizuāli telpiskas, gan nevizuālas informācijas vienlaicīgu uztveršanu un apvienošanu konsolidētā skatpunktā.

Lai gan komunikācijas efektivitāte ir sarežğīiti novērtējama, analīzes kritēriji dalẹ̄i lauj prognozēt, kā attēlotā infomācija tiek uztverta un vai auditorija spēj to saprast un pienemt arī kā savu skatpunktu vai izvirzīt jaunus argumentus. Latvijas pilsētplānošanas kontekstā vizuālie modelēšanas principi kāa neformāls, likumiski nesaistošs veids arhitektoniski telpisku koncepciju modelēšanā šobrīd netiek pietiekami novērtēts. Arhitektiem-pilsētplānotājiem vizuālo attēlojumu un vizuālās modelēšans procesa strukturēšanas un analīzes kritēriji var būt atskaites sistēma, ar kuras palīdzību izmantot mūsdien̄̄go vizuālizēšanas iespēju potenciālu. 


\section{IZMANTOTIE AVOTI}

1. Abrams, J., Hall P. Else/Where : Mapping New Cartographies of Networks and Territories. Minneapolis, MN: University of Minnesota Design Institute, 2006. $320 \mathrm{p}$.

2. Bal, M. Visual Narrativity. Routledge Encyclopedia of Narrative Theory. London and New York: Routledge, 2005. p. 629-633.

3. Blackwell,A. F. Diagrams about Thoughts about Thoughts about Diagrams. Reasoning with Diagrammatic Representations II : Papers from the AAAI 1997 Fall Symposium, Massachusetts Institute of Technology. [online]. Cambridge, Menlo Park, California: AAAI Press, 1997. pp. 77-84. [cited 15.04.2011] http://www.cl.cam.ac.uk/users/afb21/publications/AAAI.html.

4. Bolter, J. D., Grusin, R. Remediation : Understanding New Media. Cambridge: The MIT Press, 2002. 295 p.

5. Burg van den, L. Urban Analysis Guidebook : Typomorphology. Delft: DUP Science, 2004. 295 p.

6. Dühr S. The Visual Language of Spatial Planning : Exploring Cartographic Representations for Spatial Planning in Europe. London, New York: Routledge, 2007. $196 \mathrm{p}$.

7. Graafland, A. D. Understanding the Socius Through Creative Mapping Techniques. Delft: Delft School of Design, 2010. 55 p.

8. Holmes, M., Rice, A., Tomlinson, J. Will Emerging Digital Representation Tools Change our Design Judgments and Results? : A Comparison of Realities. Procedings B : Research by Design. Delft: DUP Satellite, 2001. p. 306.

9. Jong de, T. M., Voordt van der, D. J. M. Ways to Study and Research Urban, Architectural and Tecnical Design. Delft: DUP Science, 2002. 554 p.

10. Mitchell, W. J. T. Iconology : Image, Text, Ideology. Chicago and London: The University of Chicago Press, 1987. 226 p.

11. Monmonier, M. How to Lie with Maps. Chicago and London: The University of Chicago Press, 1991. 176 p.

12. Narayanan, N. H., Hübscher, R. Visual Language Theory : Towards a Human-Computer Interaction Perspective. Visual Language Theory. New York, Springer-Verlag, 1998. p. 87-129.

13. Reed, S. Research and Design. Procedings B : Research by Design. Delft: DUP Satellite, 2001. p. 262-268.

14. Rose, G. Visual Methodologies : An Introduction to the Interpretation of Visual materials. London: Sage Publications, 2007. 304 p.

15. Smets, M. Raster, Hülse, Lichtung und Montage = Grid, Casco, Clearing and Montage. Texte zur Landschaft : Essays über Entwurf, Stil, Zeit und Raum = About landscape : Essays on Design, Style, Time and Space. München: Callwey Verlag, 2002. p. 88-101.

16. Somol, R. E. Green Dots 101. Rethinking Representation : The Berlage Institute Report No.11. Rotterdam: Episode Publishers, 2007. p. 29-40. 